\title{
Palladium Charcoal-Catalyzed Suzuki-Miyaura Coupling to Obtain Arylpyridines and Arylquinolines
}

\author{
Tsuyoshi Tagata and Mayumi Nishida*
}


Supporting Information:

Experimental :

All reactions were conducted under a nitrogen atmosphere. NMR spectra were recorded in $\mathrm{CDCl}_{3}\left({ }^{1} \mathrm{H}\right.$ at $400 \mathrm{MHz}$ and ${ }^{13} \mathrm{C}$ at $\left.100 \mathrm{MHz}\right)$. All starting materials were obtained commercially. Compounds 1a-c, $1 \mathbf{f}, \mathbf{1 g}, \mathbf{1 i}, \mathbf{1 j}-\mathbf{m} \mathbf{4 a}, \mathbf{4 b}, \mathbf{5}, \mathbf{8}$ and $\mathbf{1 0}$ were purchased from Tokyo Kasei Kogyo Co., Ltd. Compound 1e was purchased from Koei Chemical Co., Ltd. Compound 1h was purchased from Wako Pure Chemical Industries, Ltd. Compound $\mathbf{4 c}$ was purchased from Sigma-Aldrich Co. All reagents and solvents were commercial grade. NE Chemcat STD 5\% Pd/C (water content 54\%) was used as $\operatorname{Pd}(0) / C$, and Degussa E 106 NE/W 5\% Pd/C (water content 53\%), Degussa E 106 NE/W 10\% Pd/C (water content 51\%), or Degussa E 105 CA/W 5\% Pd/C(water content 56\%) was used as $\mathrm{Pd}(\mathrm{II}) / \mathrm{C}$.

Method 1. General Procedure for Coupling without Additives in the Presence of $\operatorname{Pd}(0) / C$

To a solution of 2-bromopyridine (420 mg, $2.66 \mathrm{mmol})$ and phenylboronic acid (608 $\mathrm{mg}, 3.99 \mathrm{mmol})$ in DME $(10 \mathrm{~mL})$ were added $2 \mathrm{M} \mathrm{Na}_{2} \mathrm{CO}_{3}(5 \mathrm{~mL})$ and $\mathrm{NE}$ Chemcat STD 
$5 \% \mathrm{Pd} / \mathrm{C}$ (water content $54 \%)(545 \mathrm{mg}, 0.12 \mathrm{mmol})$, and the reaction mixture was then stirred at $80{ }^{\circ} \mathrm{C}$ for 9 hours. After filtration, the catalyst was washed four times with AcOEt $(15 \mathrm{~mL})$. The combined organic layers were washed with $10 \% \mathrm{NaOHaq}$ and brine, and dried over $\mathrm{Na}_{2} \mathrm{SO}_{4}$. The solvent was removed under reduced pressure. The residue was purified by silica gel column chromatography (hexane:AcOEt=5:1) to give the product 3a (213 $\mathrm{mg}, 54 \%$ yield).

Yields of $\mathbf{3 b}$-f are given in Table 1. Compounds 3a-c are commercially available from Tokyo Kasei Kogyo Co., Ltd. Compounds 3d-f, ${ }^{3 a-c)}$ are described in the literature.

Method 2. General Procedure for Coupling with TBAB in the Presence of $\operatorname{Pd}(0) / C$.

To a solution of 2-bromopyridine $(420 \mathrm{mg}, 2.66 \mathrm{mmol})$, phenylboronic acid (608 mg, $3.99 \mathrm{mmol})$ and TBAB $(86 \mathrm{mg}, 0.27 \mathrm{mmol})$ in DME $(10 \mathrm{~mL})$ were added $2 \mathrm{M} \mathrm{Na}_{2} \mathrm{CO}_{3}(5$ $\mathrm{mL}$ ) and NE Chemcat STD 5\% Pd/C (water content 54\%)(545 mg, $0.12 \mathrm{mmol}$ ), and the reaction mixture was then stirred at $80{ }^{\circ} \mathrm{C}$ for 9 hours. After filtration, the catalyst was washed four times with $\mathrm{AcOEt}(15 \mathrm{~mL})$. The combined organic layers were washed with $10 \% \mathrm{NaOHaq}$ and brine, and dried over $\mathrm{Na}_{2} \mathrm{SO}_{4}$. The solvent was removed under 
reduced pressure. The residue was purified by silica gel column chromatography (hexane:AcOEt=5:1) to give the product $\mathbf{3 a}$ (350 $\mathrm{mg}, 85 \%$ yield).

The equivalents of TBAB and the yields of products $\mathbf{3 b}-\mathbf{f}$ are given in Table 1.

Method 3. General Procedure for Coupling with $\mathrm{PPh}_{3}$

To a solution of 2-bromopyridine (420 mg, $2.66 \mathrm{mmol}$ ), phenylboronic acid (405 mg, 3.3 mmol $)$ and $\mathrm{PPh}_{3}(122 \mathrm{mg}, 0.47 \mathrm{mmol})$ in $\mathrm{DME}(10 \mathrm{~mL})$ were added $2 \mathrm{M} \mathrm{Na}_{2} \mathrm{CO}_{3}(5 \mathrm{~mL})$ and NE Chemcat STD 5\% Pd/C (water content 54\%)(545 mg, $0.12 \mathrm{mmol})$, and the reaction mixture was stirred at $80{ }^{\circ} \mathrm{C}$ for 9 hours. After filtration, the water layer was extracted twice with AcOEt $(30 \mathrm{~mL})$. The combined organic layers were washed with $10 \% \mathrm{NaOHaq}$ and brine, and dried over $\mathrm{Na}_{2} \mathrm{SO}_{4}$. The solvent was removed under reduced pressure. The residue was purified by silica gel column chromatography (hexane:AcOEt=5:1) to give the product $\mathbf{3 a}(350 \mathrm{mg}, 85 \%$ yield).

Yields of 3a-j, 6a-c, $\mathbf{7}$ are given in Table 2. Compound $\mathbf{6 a}$ is commercially available Sigma-Aldrich Co. and $\mathbf{3 g - j}{ }^{6 \mathrm{a}-\mathrm{d})}, \mathbf{6} \mathbf{b}^{6 \mathrm{ec}}, \mathbf{6} \mathbf{c}^{6 \mathrm{6f}}$ and $\mathbf{7}^{6 \mathrm{~g})}$ are described in the literature.

Method 4. General Procedure for Coupling with $\mathrm{PPh}_{3}$ in the presence of $\mathrm{Pd}(\mathrm{II}) / \mathrm{C}$ 
To a solution of 2-chloro-6-methoxypyridine (382 mg, $2.66 \mathrm{mmol}$ ), phenylboronic acid (405 mg, $3.3 \mathrm{mmol})$ and $\mathrm{PPh}_{3}(122 \mathrm{mg}, 0.47 \mathrm{mmol})$ in $\mathrm{DME}(10 \mathrm{~mL})$ were added $2 \mathrm{M}$ $\mathrm{Na}_{2} \mathrm{CO}_{3}(5 \mathrm{~mL})$ and Degussa E $106 \mathrm{NE} / \mathrm{W} 10 \% \mathrm{Pd} / \mathrm{C}$ (water content 51\%)( $259 \mathrm{mg}, 0.12$ mmol), and the reaction mixture was stirred at $80{ }^{\circ} \mathrm{C}$ for 9 hours. After filtration, the water layer was extracted twice with AcOEt $(30 \mathrm{~mL})$. The combined organic layers were washed with $10 \% \mathrm{NaOHaq}$ and brine, and dried over $\mathrm{Na}_{2} \mathrm{SO}_{4}$. The solvent was removed under reduced pressure. The residue was purified by silica gel column chromatography (hexane:AcOEt=5:1) to give the product 3a (443 mg, 90\% yield).

In the reaction of 1k, Degussa E 106 NE/W 5\% Pd/C (water content $53 \%)(545 \mathrm{mg}, 0.12$ mmol) was used instead of Degussa E 106 NE/W 10\% Pd/C (water content 51\%)(259 mg, $0.12 \mathrm{mmol}$ ). In the reactions of 11-m, 4c, and 8, Degussa E $105 \mathrm{CA} / \mathrm{W} 5 \% \mathrm{Pd} / \mathrm{C}$ (water content 56\%)(545 mg, $0.12 \mathrm{mmol})$ was used instead of Degussa E $106 \mathrm{NE} / \mathrm{W} 10 \% \mathrm{Pd} / \mathrm{C}$ (water content $51 \%)(259 \mathrm{mg}, 0.12 \mathrm{mmol})$. The yields of $\mathbf{3 i}, \mathbf{3 j}$ and $\mathbf{9}$ are given in Table 3 . Compound $\mathbf{9}$ is commercially available from Tokyo Kasei Kogyo Co., Ltd.

Method 5. The reaction with dppb, dppp or 2-(dicyclohexylphosphino)biphenyl in the presence of $\mathrm{Pd}(0) / \mathrm{C}$ 
To a solution of 3-chloropyridine (302mg, $2.66 \mathrm{mmol})$, phenylboronic acid (405 mg, 3.3 mmol) and dppb (98 mg, $0.23 \mathrm{mmol})$ in $\mathrm{DME}(10 \mathrm{~mL})$ were added $2 \mathrm{M} \mathrm{Na}_{2} \mathrm{CO}_{3}(5 \mathrm{~mL})$ and NE Chemcat STD 5\% Pd/C (water content 54\%)(545 mg, $0.12 \mathrm{mmol}$ ), and the reaction mixture was stirred at $80{ }^{\circ} \mathrm{C}$ for 9 hours. When the reaction was checked by HPLC, no desired product was observed, and only the peak of the starting material was seen in the chart. When dppp (95 $\mathrm{mg}, 0.23 \mathrm{mmol}$ ) was used instead of dppb, the same result was obtained.

To a solution of 3-chloropyridine (302mg, $2.66 \mathrm{mmol}$ ), phenylboronic acid (405 mg, 3.3 mmol) and -(dicyclohexylphosphino)biphenyl $(82 \mathrm{mg}, 0.23 \mathrm{mmol})$ in DME $(10 \mathrm{~mL})$ were added $2 \mathrm{M} \mathrm{Na}_{2} \mathrm{CO}_{3}(5 \mathrm{~mL})$ and $\mathrm{NE}$ Chemcat STD 5\% Pd/C (water content 54\%)(545 mg, $0.12 \mathrm{mmol})$. After filtration, the water layer was extracted twice with AcOEt $(30 \mathrm{~mL})$. The combined organic layers were washed with $10 \% \mathrm{NaOHaq}$ and brine, and dried over $\mathrm{Na}_{2} \mathrm{SO}_{4}$. The solvent was removed under reduced pressure. The residue was purified by silica gel column chromatography (hexane:AcOEt=5:1) to give the product 3a (363 mg, 88\% yield). Yields of $\mathbf{3 b}, \mathbf{3 c}$, and $\mathbf{6 c}$ are given in Table 4. 
Method 6. The reaction with 2-(dicyclohexylphosphino)biphenyl in the presence of $\mathrm{Pd}(\mathrm{II}) / \mathrm{C}$

To a solution of 4-methoxyphenylchloride (379 mg, $2.66 \mathrm{mmol}$ ), phenylboronic acid (405 mg, $3.3 \mathrm{mmol}$ ) and 2-(dicyclohexylphosphino)biphenyl (82 $\mathrm{mg}, 0.23 \mathrm{mmol}$ ) in DME $(10 \mathrm{~mL})$ were added $2 \mathrm{M} \mathrm{Na}_{2} \mathrm{CO}_{3}(5 \mathrm{~mL})$ and Degussa E $105 \mathrm{CA} / \mathrm{W} 5 \% \mathrm{Pd} / \mathrm{C}$ (water content $56 \%)(545 \mathrm{mg}, 0.12 \mathrm{mmol})$, and the reaction mixture was stirred at $80{ }^{\circ} \mathrm{C}$ for 9 hours. After filtration, the catalyst was washed four times with AcOEt. The combined organic layers were washed with $10 \% \mathrm{NaOHaq}$ and brine, and dried over $\mathrm{Na}_{2} \mathrm{SO}_{4}$. The solvent was removed under reduced pressure to recover 4-methoxybiphenyl (11) (392 mg, $80 \%$ yield). Compound $\mathbf{1 1}$ is commercially available from Tokyo Kasei Kogyo Co., Ltd. 